\title{
Laminin and fibronectin in adenoid cystic carcinoma
}

\author{
AJ d'ARDENNE, P KIRKPATRICK, CA WELLS, JD DAVIES* \\ From the Departments of Pathology, John Radcliffe Hospital, Headington, Oxford, and *the Bristol Royal \\ Infirmary, Bristol
}

\begin{abstract}
SUMMARY The distribution of fibronectin and laminin was examined by immunohistochemistry in 11 adenoid cystic breast carcinomas, six adenoid cystic carcinomas of mouth and salivary gland, and six cribriform ductal breast carcinomas. Both proteins were present lining cystic lumina and around tumour islands in all the adenoid cystic breast carcinomas and in five of six salivary gland tumours. Abundant laminin and fibronectin were dispersed among adenoid cystic tumour cells arranged in sheets. One adenoid cystic carcinoma from buccal mucosa showed a transition from a cribriform tumour positive for both fibronectin and laminin to a cribriform tumour negative for fibronectin and laminin to undifferentiated carcinoma. Fibronectin and laminin seemed to disappear simultaneously from tumour cell surfaces. Another adenoid cystic carcinoma from buccal mucosa was negative for fibronectin and laminin from the time of initial biopsy. This was the only tumour that gave rise to disseminated metastases, resulting in the death of the patient within two years of surgery. In cribriform invasive ductal breast carcinomas the linings of cystic lumina were always negative for fibronectin and laminin. Varying quantities were present at the tumour boundaries. We suggest that staining for fibronectin and laminin may be a valuable aid to the diagnosis of adenoid cystic carcinomas and that the absence of these proteins may have important prognostic implications.
\end{abstract}

Adenoid cystic carcinomas are tumours which arise most often in the mouth and salivary glands, but which may also occur in other sites-namely, the tracheobronchial tree, nasopharynx, maxillary sinus, uterine cervix, skin and breast. ${ }^{1-5}$ They are composed of two cell types: those resembling myoepithelial cells and duct lining cells. Myoepithelial like cells are predominant. In adenoid cystic carcinomas with the classical cribriform pattern, groups of cells are separated to form false cysts, which on ultrastructural examination are seen to be lined by basal lamina. ${ }^{6-8}$ True ductal lumina are also present. In some adenoid cystic carcinomas false cysts are less conspicuous, and there is a sheet like pattern of growth. Adenoid cystic carcinomas of the mouth and salivary glands are usually slow growing if infiltrative but may display more overtly aggressive behaviour and give rise to disseminated metastasis. ${ }^{2}$ In some cases this is preceded by transformation to carcinomas with a more anaplastic morphology. Local recurrences are common. Adenoid cystic carcinomas of the breast are generally associated with a better prognosis. ${ }^{3910}$ It is therefore important to distinguish them from the more common invasive ductal carcinomas,

Accepted for publication 4 September 1985 some of which display a cribriform pattern. ${ }^{11}$ This distinction may present a problem. ${ }^{3}$

Fibronectin and laminin are both non-collagenous glycoproteins associated with basal lamina. ${ }^{1213}$ Fibronectin is also found in interstitial connective tissue and in extracellular body fluids. ${ }^{14}$ Ultrastructural immunohistochemistry has localised laminin to both the lamina rara and lamina densa of basement membranes ${ }^{1516}$; the precise localisation of fibronectin is more controversial. ${ }^{1417-19}$ A previous study showed the presence of fibronectin lining the cystic spaces of an adenoid cystic carcinoma of the submandibular salivary gland. ${ }^{20}$ In this study we compared the distribution of fibronectin and laminin in a series of adenoid cystic carcinomas from breast with their distribution in cribriform ductal carcinomas of breast and in adenoid cystic carcinomas of the mouth and salivary gland. The aim was to determine whether staining for fibronectin and laminin may be of value in diagnosing these tumours and whether the presence of these proteins has any prognostic implications.

\section{Material and methods}

Tissue was examined from eleven adenoid cystic 
Table 1 Adenoid cystic carcinomas of mouth and salivary glands

\begin{tabular}{|c|c|c|c|c|}
\hline Case No & $\begin{array}{l}\text { Age and sex at } \\
\text { diagnosis }\end{array}$ & Site & $\begin{array}{l}\text { Time since } \\
\text { diagnosis }\end{array}$ & Outcome \\
\hline $\begin{array}{l}1 \\
2 \\
3 \\
4 \\
5\end{array}$ & $\begin{array}{ll}50 & \mathrm{~F} \\
64 & \mathrm{~F} \\
61 & \mathrm{~F} \\
77 & \mathrm{~F} \\
61 & \mathrm{M}\end{array}$ & $\begin{array}{l}\text { Parotid gland } \\
\text { Submandibular gland } \\
\text { Buccal mucosa } \\
\text { Parotid gland } \\
\text { Buccal mucosa }\end{array}$ & $\begin{array}{l}12 \text { years } \\
5 \text { years } \\
3 \text { months } \\
3 \text { years } \\
5 \text { years }\end{array}$ & $\begin{array}{l}\text { Alive and well; four local recurrences } \\
\text { Alive and well; no local recurrence } \\
\text { Alive and well; good initial recovery } \\
\text { Alive and well; one local recurrence } \\
\text { Died when transition to } \\
\text { undifferentiated carcinoma } \\
\text { occurred with extensive local } \\
\text { recurrence } 5 \text { years after diagnosis }\end{array}$ \\
\hline 6 & $57 \mathrm{~F}$ & Buccal mucosa & 18 months & $\begin{array}{l}\text { Died } 18 \text { months after diagnosis } \\
\text { with lymph node, lung, and } \\
\text { bone metastases }\end{array}$ \\
\hline
\end{tabular}

breast carcinomas, six adenoid cystic carcinomas of the mouth and salivary gland, and six cribriform invasive ductal breast carcinomas. All of the tissue used in the study was paraffin embedded. Most was fixed in formalin, but in a few instances when patients had been referred from elsewhere the mode of fixation was unknown. Sections were stained for fibronectin and laminin by the indirect immunoperoxidase method following protease digestion: details of this method have been described previously. ${ }^{2122}$ Rabbit antibody to human fibronectin and peroxidase conjugated antirabbit IgG were obtained from Dakopatts, Mercia Brocades Ltd. Rabbit antilaminin antibody was obtained from Bethesda Research Laboratories. All antisera were diluted 1/50 in phosphate buffered saline, pH 7.3. Effectiveness of the technique was judged by the staining of basal lamina in blood vessels and around normal breast acini. These structures acted as an internal positive control. Negative controls were incubated with non-immune rabbit IgG or with phosphate buffered saline in place of the primary antiserum.

\section{Results}

\section{ADENOID CYSTIC CARCINOMA OF THE MOUTH AND SALIVARY GLANDS}

Table 1 summarises the clinical details of these cases. Four of the six tumours (cases 1-4) showed strong positive staining for fibronectin and laminin along cell boundaries both within and at the periphery of tumour islands. The immunostaining was seen lining pseudocysts, along the margins of epithelial cell cords, and abundantly between those tumour cells which were arranged in sheets (Fig. 1). This staining pattern was present in local recurrences as well as in the initial tumour. Only one case (2) showed focal cytoplasmic staining for laminin (Fig. 2). No intracellular fibronectin was shown.

In case 5 there was a transition from typical adenoid cystic carcinoma to a poorly differentiated car- cinoma with a focally squamoid appearance. In one part of the tumour fibronectin and laminin were present lining pseudocystic lumina and peripherally around individual islands of carcinoma cells. Adjacent tumour cells showed retention of the classical cribriform pattern but loss of fibronectin and laminin (Fig. 3). Staining consecutive serial sections for both these proteins suggested that they were lost simultaneously, initially from the pseudocystic spaces and subsequently from the tumour boundaries. The cribriform tumour negative for fibronectin and laminin merged into a poorly differentiated carcinoma in which laminin staining was discontinuous and irregular at the margins, or was completely absent. Fibronectin showed a similar distribution but was found in increased amounts in the tumour stroma. Case 6 was a carcinoma of cribriform appearance in which cystic lumina were negative for both fibronectin and laminin from the time of initial biopsy. Scanty and fragmented laminin was evident at some tumour boundaries but most were negative. Parts of the tumour were less well differentiated and these showed increased stromal fibronectin.

\section{ADENOID CYSTIC CARCINOMAS OF BREAST}

Table 2 summarises the clinical details of these cases. Fibronectin and laminin were seen lining pseudocystic spaces within all these tumours (Fig. 4). Where tumour cells were arranged in sheets fibronectin and laminin were dispersed irregularly among them and sometimes outlined small pseudocysts that were not otherwise readily detectable. Only one case showed focal intracytoplasmic staining for laminin. Both proteins were present around the periphery of tumour cell islands. In a few cases laminin staining appeared weak and patchy, but as this applied to normal structures as well as to the tumour it was attributed to staining artefact. These findings may have been the result of the method of fixation rather than attributable to a genuine difference in distribution of laminin. 


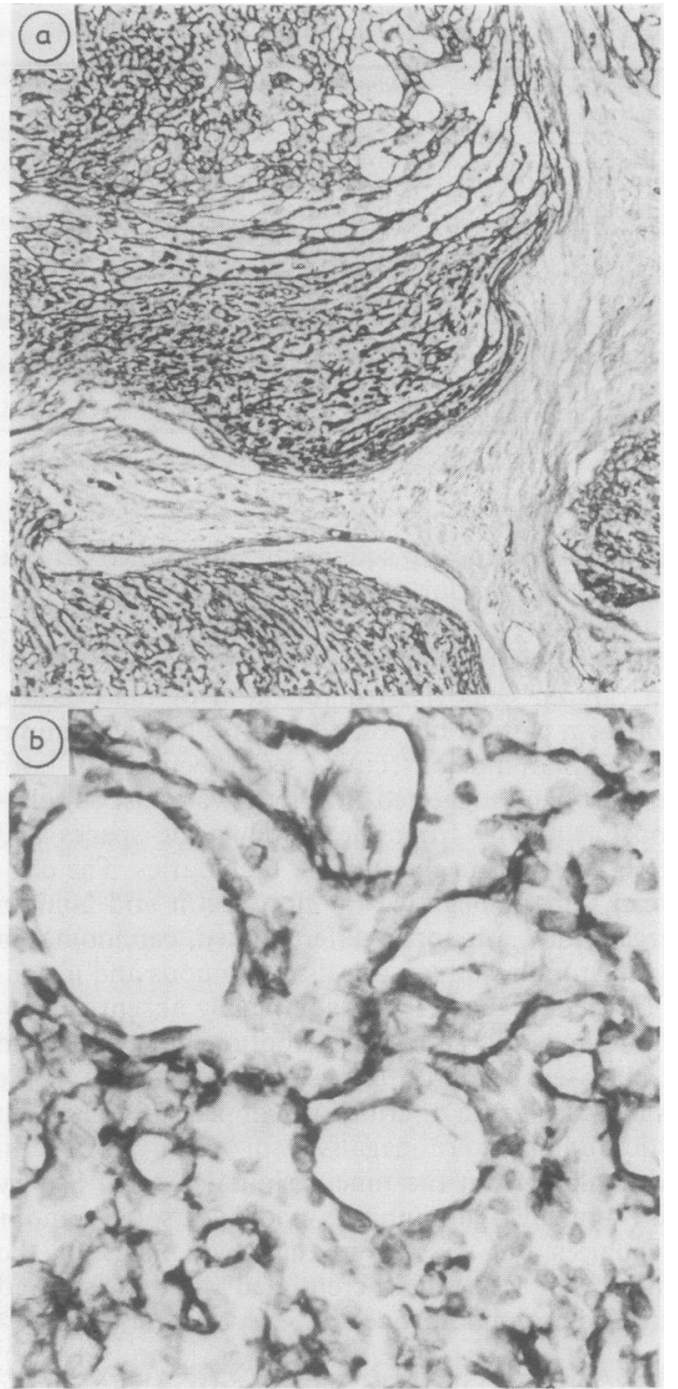

Fig. 1a Adenoid cystic carcinoma of parotid gland (case 4) showing abundant laminin (black) among tumour cells arranged in sheets. (Immunoperoxidase haematoxylin.) $\times 250$.

Fig. lb Adenoid cystic carcinoma of parotid gland (case 4) showing laminin lining small cysts within tumour.

(Immunoperoxidase haematoxylin.) $\times 400$.

\section{CRIBRIFORM DUCTAL CARCINOMAS OF}

BREAST

Table 3 gives the clinical details of these cases. Both fibronectin and laminin outlined the basement membranes of ducts containing intraductal carcinoma, but neither was seen lining cystic spaces within tumour masses (Figs. 5 and 6). Basement membrane staining

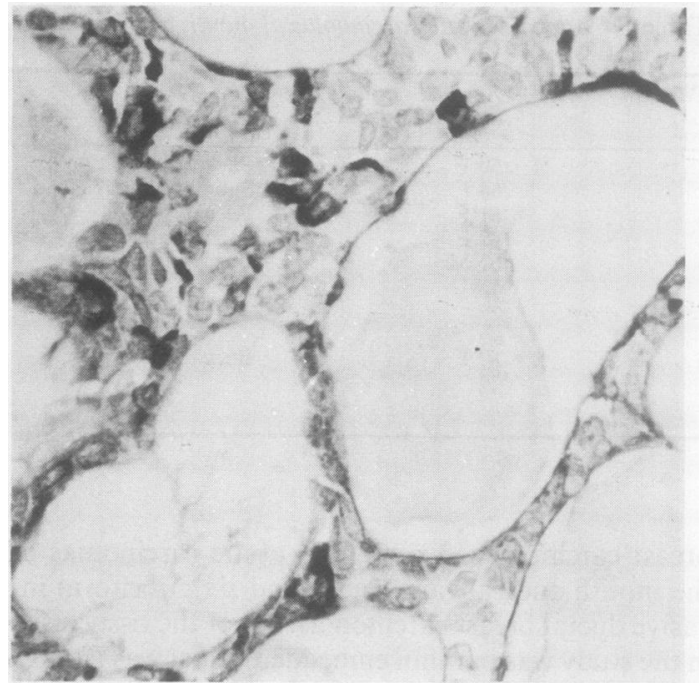

Fig. 2 Adenoid cystic carcinoma of submandibular gland (case 2) showing laminin lining cysts and focally within tumour cell cytoplasm. (Immunoperoxidase haematoxylin.) $\times 400$.

around the in situ component of the carcinomas was usually continuous, but a single section of one tumour. showed a duct with focal discontinuity of basement membrane laminin (Fig. 6). Laminin staining around the invasive carcinoma was discontinuous or absent. None was shown in the cytoplasm of the tumour cells.

In contrast to its distribution in normal breast tissue and adenoid cystic carcinoma, fibronectin in invasive ductal carcinoma differed substantially from that of laminin. It was focally abundant in the stroma of tumour and was also present in irregular condensations of fibres around infiltrating islands of carcinoma. The linings of cysts in cribriform carcinomas were always negative, although diffuse staining for fibronectin was sometimes evident in the central areas of necrosis. One carcinoma showed weak focal cytoplasmic positivity for fibronectin.

All sections incubated with non-immune rabbit IgG or with phosphate buffered saline in place of the primary antiserum were negative. In sections staining positively for fibronectin there was a strong reaction in mast cell granules, as noted previously. ${ }^{23}$

\section{Discussion}

This study indicates that fibronectin and laminin staining may be a valuable aid in the diagnosis of adenoid cystic carcinoma. The technique readily distinguishes between the pseudocysts lined with basal lamina of an adenoid cystic tumour and the cysts negative for fibronectin and laminin present in other carcinomas with a cribriform pattern. Its advantage 

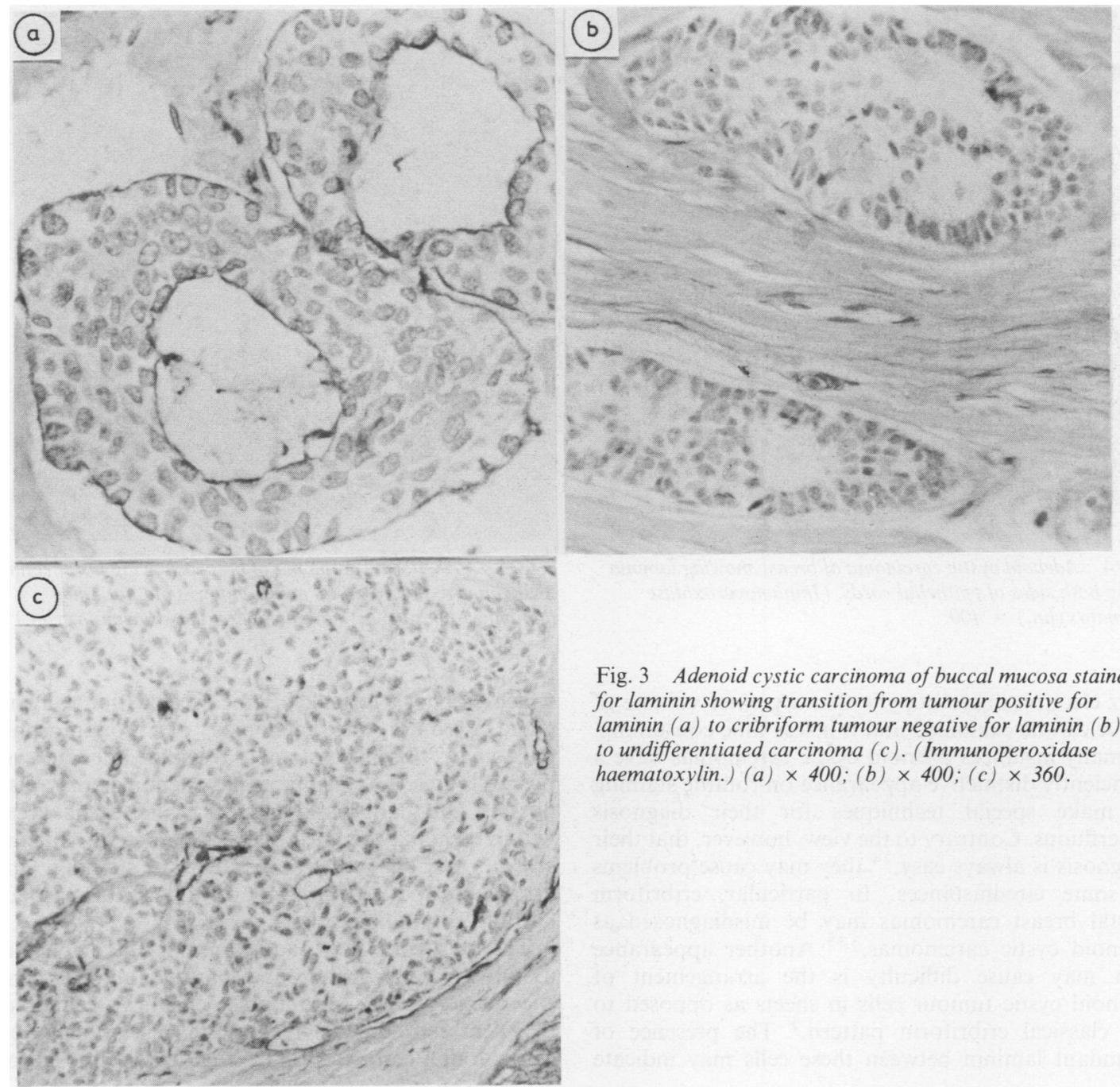

Fig. 3 Adenoid cystic carcinoma of buccal mucosa stained for laminin showing transition from tumour positive for laminin (a) to cribriform tumour negative for laminin (b) to undifferentiated carcinoma $(c)$. (Immunoperoxidase haematoxylin.) (a) $\times 400 ;($ b $) \times 400 ;(c) \times 360$.

Table 2 Adenoid cystic carcinomas of breast

\begin{tabular}{|c|c|c|c|c|}
\hline Case No & $\begin{array}{l}\text { Age and sex at } \\
\text { diagnosis }\end{array}$ & Site & $\begin{array}{l}\text { Time since } \\
\text { diagnosis }\end{array}$ & Outcome \\
\hline 7 & $54 \mathrm{~F}$ & Breast & $51 / 2$ years & $\begin{array}{l}\text { Local intermittent breast pain; } \\
\text { no recurrence or metastasis }\end{array}$ \\
\hline $\begin{array}{r}8 \\
9 \\
10\end{array}$ & $\begin{array}{l}\mathrm{F} \\
58 \mathrm{~F} \\
47 \mathrm{~F}\end{array}$ & $\begin{array}{l}\text { Breast } \\
\text { Breast } \\
\text { Breast }\end{array}$ & $\begin{array}{l}\text { Not known } \\
9 \text { years } \\
4 \text { years }\end{array}$ & $\begin{array}{l}\text { No known recurrence } \\
\text { Local recurrence at } 4 \text { years; }\end{array}$ \\
\hline $\begin{array}{l}11 \\
12\end{array}$ & $\begin{array}{l}74 \mathrm{~F} \\
55 \mathrm{~F}\end{array}$ & $\begin{array}{l}\text { Breast } \\
\text { Breast }\end{array}$ & $\begin{array}{r}5 \text { years } \\
18 \text { years }\end{array}$ & $\begin{array}{l}\text { No recurrence or metastasis } \\
\text { Local chest wall recurrence at } \\
15 \text { years; no metastasis }\end{array}$ \\
\hline $\begin{array}{l}13 \\
14 \\
15 \\
16 \\
17\end{array}$ & $\begin{array}{l}F \\
66 \mathrm{~F} \\
60 \mathrm{~F} \\
F \\
67 \mathrm{~F}\end{array}$ & $\begin{array}{l}\text { Breast } \\
\text { Breast } \\
\text { Breast } \\
\text { Breast } \\
\text { Breast }\end{array}$ & $\begin{array}{l}3 \text { years } \\
5 \text { years } \\
2 \text { years }\end{array}$ & $\begin{array}{l}\text { No information } \\
\text { No local recurrence } \\
\text { Bilaterial mastectomy } \\
\text { No known recurrence }\end{array}$ \\
\hline
\end{tabular}




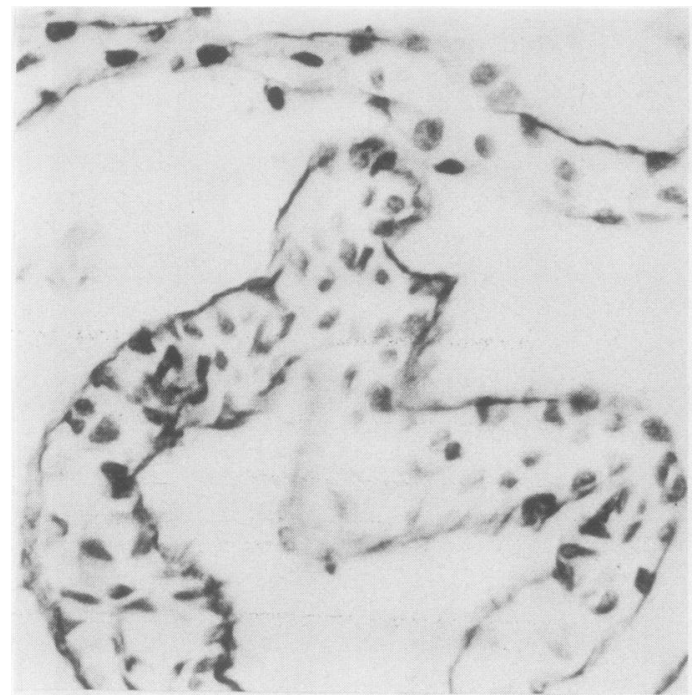

Fig. 4 Adenoid cystic carcinoma of breast showing laminin lining both sides of epithelial cords. (Immunoperoxidase haematoxylin.) $\times 400$.

over electron microscopy is that a greater volume of tissue can be examined and it is less time consuming. In many instances adenoid cystic carcinomas have a sufficiently distinctive appearance on routine staining to make special techniques for their diagnosis superfluous. Contrary to the view, however, that their diagnosis is always easy, ${ }^{24}$ they may cause problems in some circumstances. In particular, cribriform ductal breast carcinomas may be misdiagnosed as adenoid cystic carcinomas. ${ }^{325}$ Another appearance that may cause difficulty is the arrangement of adenoid cystic tumour cells in sheets as opposed to the classical cribriform pattern. ${ }^{2}$ The presence of abundant laminin between these cells may indicate

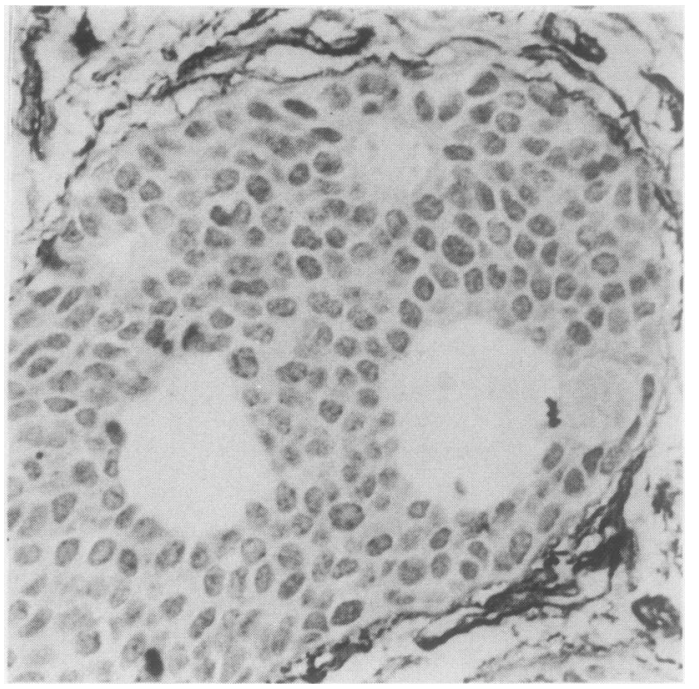

Fig. 5 Cribriform carcinoma of breast showing fibronectin associated with interstitial collagen fibres but not lining lumina within tumour. (Immunoperoxidase haematoxylin.) $\times 400$.

which diagnosis to make. Some areas within salivary gland pleomorphic adenomas or monomorphic adenomas $^{26}$ may occasionally resemble adenoid cystic carcinoma. ${ }^{2}$ As pleomorphic adenomas may also possess abundant basal lamina ${ }^{20}$ and cystic areas within them may be lined by basal lamina (d'Ardenne et al, unpublished observations) staining for fibronectin and laminin is not of value in this particular differential diagnosis.

The most important factor limiting-the diagnostic usefulness of fibronectin and laminin staining is the effectiveness of the immunohistochemical technique. Excellent reproducible results are usually achieved with paraffin embedded tissue that has been fixed for

Table 3 Non-adenoid cystic carcinoma of breast

\begin{tabular}{|c|c|c|c|c|c|}
\hline $\begin{array}{l}\text { Case } \\
\text { No }\end{array}$ & $\begin{array}{l}\text { Age and sex } \\
\text { at diagnosis }\end{array}$ & Site & $\begin{array}{l}\text { Time since } \\
\text { diagnosis }\end{array}$ & Outcome & Diagnosis \\
\hline$\overline{18}$ & $64 \mathrm{~F}$ & Breast & 5 years & $\begin{array}{l}\text { No recurrence or } \\
\text { metastasis }\end{array}$ & Atypical lobular proliferation \\
\hline 19 & $55 \mathrm{~F}$ & Breast & 3 years & $\begin{array}{l}\text { No recurrence or } \\
\text { metastasis }\end{array}$ & Invasive cribriform carcinoma \\
\hline 20 & $52 \mathrm{~F}$ & Breast & 1 year & $\begin{array}{l}\text { No recurrence or } \\
\text { metastasis }\end{array}$ & Invasive cribriform carcinoma \\
\hline 21 & $51 \mathrm{~F}$ & Breast & 3 months & $\begin{array}{l}\text { No recurrence or } \\
\text { metastasis }\end{array}$ & Invasive cribriform carcinoma \\
\hline $22 *$ & $46 \mathrm{~F}$ & Breast & & & $\begin{array}{l}\text { Invasive cribriform carcinoma } \\
\text { "Pseudo ACC"" }\end{array}$ \\
\hline 23 & $43 \mathrm{~F}$ & Breast & 2 months & $\begin{array}{l}\text { No recurrence or } \\
\text { metastasis }\end{array}$ & Invasive cribriform carcinoma \\
\hline 24 & $66 \mathrm{~F}$ & Breast & 1 month & $\begin{array}{l}\text { No recurrence or } \\
\text { metastasis }\end{array}$ & Invasive cribriform carcinoma \\
\hline
\end{tabular}

*Previously published by Harris. ${ }^{36}$ 


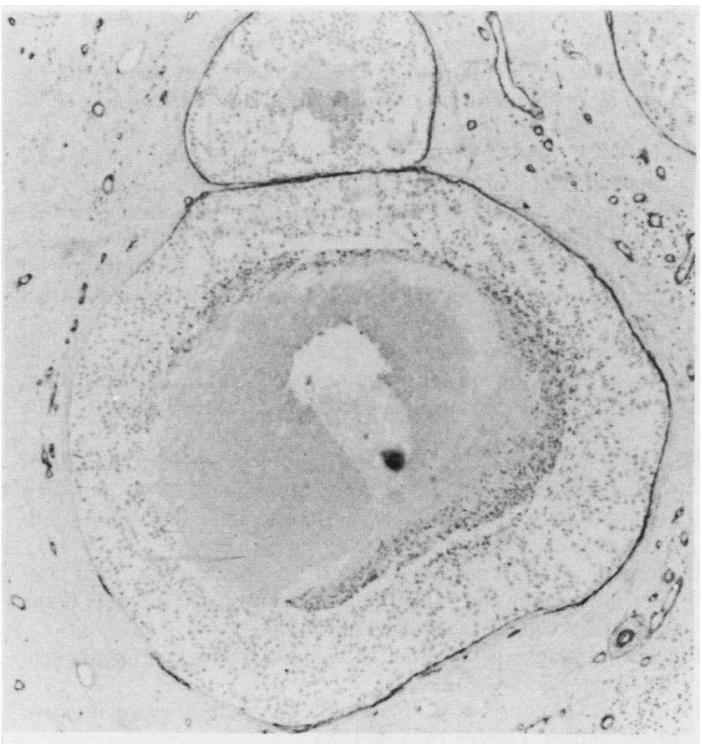

Fig. 6 Intraduct carcinoma of breast showing discontinuous laminin staining in basement membrane of duct.

(Immunoperoxidase haematoxylin.) $\times 80$.

up to 48 hours in formalin, but variations in fixation may affect the antigenicity of these matrical proteins. ${ }^{21}$ Trypsin is unsatisfactory for "unmasking" laminin and fibronectin antigens in formalin fixed tissue, and pepsin or pronase should be used. ${ }^{21}$ Fortunately, almost all tissue sections incorporate inbuilt positive controls in the form of blood vessels and other normal structures possessing basal lamina. It is therefore easy to determine if the result is genuinely negative, or negative due to inadequate staining.

Loss of fibronectin and laminin by an adenoid cystic carcinoma may occur during transformation to a more aggressive malignancy, as shown in this series (case 5). Case 6 was the only tumour of apparent adenoid cystic morphology (although the diagnosis may be open to question) that was negative for fibronectin and laminin from the time of initial biopsy. This was also the only case in which the patient died with disseminated metastases within two years of surgery. Such findings suggest that the presence or absence of fibronectin and laminin may have important prognostic implications. A larger series with longer follow up would be required to verify this hypothesis. Nevertheless, adenoid cystic breast carcinomas have a better prognosis than those found in salivary glands, ${ }^{39}$ and it is noteworthy that none was negative for fibronectin and laminin in our series. Prognosis may be related to site for several reasons, including the ease of complete excision. Both the cases resulting in death in the present series arose in buccal mucosa where adequate excision is sometimes difficult.

Interestingly, the case, in which there was a morphological transition in the tumour from positivity for fibronectin and laminin to absence of fibronectin and laminin staining of consecutive serial sections, suggested that these two proteins were lost simultaneously from the tumour cell margins. A similar phenomenon was observed in a leiomyosarcoma from the ileum. ${ }^{23}$ These findings resemble the simultaneous loss of fibronectin, laminin, and heparan sulphate proteoglycan from the surfaces of cultured rat kidney cells after viral transformation. ${ }^{27}$ They suggest that there is a close relation between the expression of fibronectin and laminin. The parallel microanatomical distribution of these proteins points to fibronectin as a genuine constituent of basal lamina. It has been clearly shown that it is not exclusively associated with interstitial collagen, fibronectin being found in sites where interstitial collagen is absent. ${ }^{132023}$ The differing distribution of fibronectin and laminin in invasive ductal carcinoma of the breast may nevertheless be explained by increased production of fibronectin, together with interstitial collagen, while basal lamina material is progressively lost. Differing interpretations of the relation of fibronectin around invasive carcinoma to stroma or tumour cells may account for discrepancies in the reported distribution of fibronectin in breast cancer. ${ }^{142028}$ Stampfer et al reported the presence of fibronectin around the entire external surface of infiltrating breast carcinoma cells, with the exception of an undifferentiated carcinoma from which it was absent. $^{29}$ Labat-Robert et al described loss of fibronectin from carcinoma cell membranes and partial loss in dysplasia. ${ }^{30}$ Similar discrepant observations have been recorded on cells cultured from breast cancer in man. ${ }^{29} 3132$

The distribution of laminin in ductal breast carcinomas noted in this study accords with other reports, although no intracytoplasmic laminin was shown. ${ }^{33-35}$ Discontinuous basement membrane laminin around intraductal breast carcinoma has been observed previously, ${ }^{34}{ }^{35}$ and this was seen in one case in the present investigation. The importance of this finding with regard to tumour invasion remains to be determined. Laminin was only seen intracellularly in two of the sixteen adenoid cystic carcinomas studied, one from the breast and one from a submandibular gland. In both cases cytoplasmic staining was focal only and possibly related to excessive production of basal lamina.

We conclude that immunostaining for fibronectin and laminin is worthwhile to help make the distinction between genuine adenoid cystic carcinomas and morphologically similar tumours. 
We thank all those colleagues who allowed us to study their material. Cases were received from Drs PD James, Nottingham; DGD Wight, Cambridge; G Garrett, Oldham; DJ Pollock, London; RT Heimann, Brussels; RG Woodcock, Bolton; DA Levison, London; MEH Halford, Weston-super-Mare; M Harris, Manchester; A Scott, Salisbury; N Gubbay, Cheltenham; and Professor NM Gibbs, Guildford.

Our thanks are also due to Mr G Richardson and Mrs MR Lake for photographic and secretarial help.

Financial support from the Department of Health and Social Security and the Trustees of the Bristol and Weston Health Authority is gratefully acknowledged.

\section{References}

${ }^{1}$ Azzopardi JG, Smith OD. Salivary gland tumours and their mucins. Journal of Pathology and Bacteriology 1959;77:131-40.

${ }^{2}$ Lucas RB. Pathology of tumours of the oral tissues. London: Churchill Livingstone, 1976:329-35.

${ }^{3}$ Azzopardi JG. Problems in breast pathology. London: WB Saunders, 1979:335-9.

${ }^{4}$ Anthony PP, James PD. Adenoid cystic carcinoma of the breast: prevalence, diagnostic criteria and histogenesis. J Clin Pathol 1975;28:647-55.

${ }^{5}$ Lawrence JB, Mazur MT. Adenoid cystic carcinoma: a comparative pathologic study of tumors in salivary gland, breast, lung and cervix. Hum Pathol 1982;13:916-24.

${ }^{6}$ Tandler B. Ultrastructure of adenoid cystic carcinoma of salivary gland origin. Lab Invest 1971;24:504-12.

${ }^{7}$ Koss LG, Brannan CD, Ashikari R. Histologic and ultrastructural features of adenoid cystic carcinoma of the breast. Cancer 1970;26:1271-9.

${ }^{8}$ Gould VE, Miller J, Jao W. Ultrastructure of medullary, intraductal, tubular and adenocystic breast carcinomas: comparative patterns of myoepithelial differentiation and basal lamina formation. Am J Pathol 1975;78:401-7.

${ }^{9}$ Bassler R. Pathologie der Brustdrüse. Berlin: Springer-Verlag, 1978:656-63.

${ }^{10}$ Cavanzo FJ, Taylor HB. Adenoid cystic carcinoma of the breast: an analysis of 21 cases. Cancer 1969;24:740-5.

${ }^{11}$ Page DL, Dixon JM, Anderson TJ, Lee D, Stewart HJ. Invasive cribriform carcinoma of the breast. Histopathology 1983; 7:525-36.

${ }^{12}$ Timpl R, Rohde H, Gehron Robey P, Rennard SI, Foidart JM, Martin GR. Laminin-a glycoprotein from basement membranes. J Biol Chem 1979;254:9933-7.

${ }^{13}$ D'Ardenne AJ, Burns J, Sykes BC, Kirkpatrick P. Comparative distribution of fibronectin and type III collagen in normal human tissues. J Pathol 1983;141:55-69.

${ }^{14}$ D'Ardenne AJ, McGee JO'D. Fibronectin in disease. $J$ Pathol 1984;142:235-51.

${ }^{15}$ Foidart JM, Bere EW, Year M, et al. Distribution and immunoelectron microscopic localisation of laminin, a noncollagenous basement membrane glycoprotein. Lab Invest 1980;42:336-42.

${ }^{16}$ Martinez-Hernandez A, Chung AE. The ultrastructural localisation of two basement membrane components: entactin and laminin in rat tissues. $J$ Histochem Cytochem 1984;32:289-98.

${ }^{17}$ Boselli JM, Macarak EJ, Clark CC, Brownell AG, MartinezHernandez A. Fibronectin: its relationship to basement mem- branes. I. Light microscopic studies. Coll Relat Res 1981;5:391-404.

${ }^{18}$ Gil J, Martinez-Hernandez A. The connective tissue of the rat lung: electron immunohistochemical studies. J Histochem Cytochem 1984;32:230-8.

${ }^{19}$ Laurie GW, Leblond CP, Martin GR. Localisation of type IV collagen, laminin, heparan sulphate proteoglycan and fibronectin to the basal lamina of basement membranes. $J$ Cell Biol 1982;95:340-4.

${ }^{20}$ D'Ardenne AJ, Burns J, Sykes BC, Bennett MK. Fibronectin and type III collagen in epithelial neoplasms of gastrointestinal tract and salivary gland. J Clin Pathol 1983;36:756-63.

${ }^{21}$ Kirkpatrick P, D'Ardenne AJ. The effects of fixation and enzymatic digestion on the immunohistochemical demonstration of laminin and fibronectin in paraffin embedded tissue. $J$ Clin Pathol 1984;37:639-44.

${ }^{22}$ Sinclair RA, Burns J, Dunnill MS. Immunoperoxidase staining of formalin-fixed, paraffin-embedded, human renal biopsies with a comparison of the peroxidase-anti-peroxidase (PAP) and indirect methods. J Clin Pathol 1981;34:859-65.

${ }^{23}$ D'Ardenne AJ, Kirkpatrick P, Sykes BC. The distribution of laminin, fibronectin and interstitial collagen type III in soft tissue tumours. J Clin Pathol 1984;37:895-904.

${ }^{24}$ Linell F, Ljungberg O. Atlas of breast pathology. Copenhagen: Munksgaard, 1984:218.

${ }^{25}$ Fisher ER, Gregoris RM, Fisher B. The pathology of invasive breast cancer. Cancer 1975;36:1-85.

${ }^{26}$ Batsakis JG, Brannon RB, Sciubba JJ. Monomorphic adenomas of major salivary glands: a histologic study of 96 tumours. Clin Otolaryngol 1981;6:129-43.

${ }^{27}$ Hayman EG, Oldberg A, Martin GR, Ruoslahti E. Codistribution of heparan sulphate proteoglycan, laminin and fibronectin in the extracellular matrix of normal rat kidney cells and their coordinate absence in transformed cells. J Cell Biol 1982;94:28-35.

${ }^{28}$ Birembaut P, Caron Y, Adnet JJ, Foidart JM. Usefulness of basement membrane markers in tumoural pathology. $J$ Pathol 1985; 145:283-96.

${ }^{29}$ Stampfer MR, Vlodavsky I, Smith HS, Ford R, Becker FF, Riggo J. Fibronectin production by human mammary cells. Journal of the National Cancer Institute 1981;67:253-61.

${ }^{30}$ Labat-Robert J, Birembaut P, Robert L, Adnet JJ. Modification of fibronectin distribution pattern in solid human tumours. Diag Histopathol 1981;4:299-306.

${ }^{31}$ Smith HS, Riggs JL, Mosesson MW. Production of fibronectin by human epithelial cells in culture. Cancer Res 1979;39:4138-44.

${ }^{32}$ Yang N-S, Kirkland W, Jorgenson T, Furmanski P. Absence of fibronectin and presence of plasminogen activator in both normal and malignant human mammary epithelial cells in culture. $J$ Cell Biol 1980;84:120-30.

${ }^{33}$ Albrechtson R, Neilson M, Wewer U, Engvall E, Ruoslahti E. Basement membrane changes in breast cancer detected by immunohistochemical staining for laminin. Cancer Res 1981;41:5076-81.

${ }^{34}$ Birembaut P, Caron Y, Van Cawenberger D, Foidart JM. Distribution of laminin, a basement membrane glycoprotein in epithelial proliferations. Coll Relat Res 1983;3:25-31.

${ }^{35}$ Gusterson BA, Warburton MJ, Mitchell D, Ellison M, Munro Neville A, Rudland PS. Distribution of myoepithelial cells and basement membrane proteins in the normal breast and in benign and malignant breast diseases. Cancer Res 1982;42:4763-70.

${ }^{36}$ Harris M. Pseudoadenoid cystic carcinoma of the breast. Arch Pathol Lab Med 1977;101:307-9.

Requests for reprints to: Dr AJ d'Ardenne, Department of Histopathology, St Bartholomew's Hospital, London EC1A 7BE, England. 